\title{
Human Well-Being and Pandemic Crisis: Implications for Social Work Practice from Kerala Experience
}

Elsa Mary Jacob, ${ }^{\dagger}$ Arya Chandran $\mathrm{L}^{{ }^{*}}$ and Abraham P. Francis ${ }^{\uparrow}$

\section{Abstract}

Nipah virus, the consecutive 2018 and 2019 floods, the internal social, economic and political struggles have had a significant impact on the lives of people in Kerala, India. While the state of Kerala was trying to get back to some form of stability, Covid-19 slams into, in an unprecedented way, drastically disrupting the lives of many. It has shaken the interconnectedness and interdependence of families and placed communities in a state of fear, anxiety and uncertainty. This article is about the vulnerabilities, experiences, voices and untold stories of courage and resilience among people in Kerala. Authors present a reflective analysis of the multidimensional impact of Covid-19 on the ordinary lives of the people of Kerala.

The deleterious impact of the Covid-19 pandemic on the entire humanity reckons the attention of governments, economists, educators, social scientists, medical and allied professionals, including social workers, to make concerted efforts to preserve and promote human well-being. Taking into consideration the structural inequalities in society, the present paper utilises a critical social work theoretical lens to analyse how it has impacted the well-being of people, especially the marginalised and vulnerable communities in Kerala.

Keywords: Well-being; Covid-19; Critical Perspectives in Social Work; Kerala; India

\footnotetext{
${ }^{\dagger}$ An Academic in Social Work, Bharata Mata College, Kerala, India, Email: els.joe@gmail.com

¥ Assistant Professor of Social Work, Bharata Mata College, India

${ }^{*}$ Corresponding Author, Email: laryachandran@gmail.com

${ }^{i}$ Associate Professor, Head of Academic Group in Social Work and Human Services, James Cook University, Australia, Email: abraham.francis@jcu.edu.au

(C) 2020 Jacab et al. This is an Open Access article distributed under the terms of the Creative Commons Attribution License (http://creativecommons.org/licenses/by/2.0), which permits unrestricted use, distribution, and reproduction in any medium, provided the original work is properly cited.
} 


\section{Introduction}

Globally and locally, Covid-19 impact on ordinary human lives transcended the phenomena of development and well-being beyond imagination, posing challenges even to mere human existence. In many countries, including India rising unemployment, decreased income, reverse migration, increasing family and domestic violence against women and children, have been noticed. This lethal combination has heightened psychological distress among people requiring the attention of social work to mental well-being (Dave, 2020; Marques et al., 2020; Sher, 2020). Mental health is a state of mental well-being in which people cope well with the many stresses of life, can realise their own potential, can function productively and fruitfully, and can contribute to their communities (WHO, 2018).

Well-being is a concrete entity encompassing human life in all spheres. It is defined as the state of being comfortable, healthy, or happy. Wellbeing is a positive outcome that is meaningful for people and many sectors of society because it tells us that people perceive that their lives are going well. Good living conditions (for example, housing, employment) are fundamental to wellbeing. Well-being can be understood as to how people feel and how they function, on both a personal and a social level, and how they evaluate their lives as a whole (New Economic Foundation, 2012). Under the larger umbrella of macro realities, well-being is also explained as a positive experience that people can evaluate in their lives (NCBI Resources, 2013).

The first case of Covid-19 in India was reported in Kerala on 30th January, 2020, through a student who had come for a vacation from Wuhan, China (Unnithan, 2020). The small state of Kerala, down south of India, known for its scenic attractions, rich heritage and culture, also took to Covid-19 pandemic. The two key factors - gulf emigrants and tourism - which were the State's economic strengths in the development chronicle became its weaknesses in containing the spread of the virus. The emigrants, mainly from the gulf provinces of the Middle East whose remittances hitherto uplifted the economy and the tourism prospects that favoured the State so far, exposed the State to the transmission of the virus. It exacerbated the condition as the State was rowing back to normalcy after history's worst floods in 2018 and its devastating repeat in 2019 (Balakrishnan, 2019).

The impact of Covid-19 pandemic at the micro (individual) and macro (societal) levels deserves in-depth reflection and analysis in our mission to bring the 'new normal'. Though there is extant literature focusing on the impact of Covid-19 on individuals, families, and groups, the emerging discussion is based on the numbers that have become unemployed, economic recession, and decline of market systems. The present article has been formulated based on collaborative discussions, analyses of news reports, social media commentary, and experiences from the field engagements during the period March to July 2020. We have also made an attempt here to consider the impacts of Covid-19 from a critical social work perspective.

This paper unpacks the complex impacts of Covid-19 on the wellbeing of the people of Kerala and has reflected on the position and scope of social work in addressing the pandemic. Finally, the paper suggests the remedial, restoration, preventive and strength based approach for human empowerment.

\section{Methodology}

This paper is a reflective analysis of the Covid-19 on the lives of the ordinary in Kerala, a critical examination of how micro and macro systems are mutually affected. The paper examines at the human experiences in the pandemic. The conclusions are based on the inferences made from personal interactions, collaborative discussions, media reports and field engagements, scientifically recorded and thematically analysed, considering justice and well-being as the crux of human life. Figure 1 presents how Kerala was hit by Covid 19. 


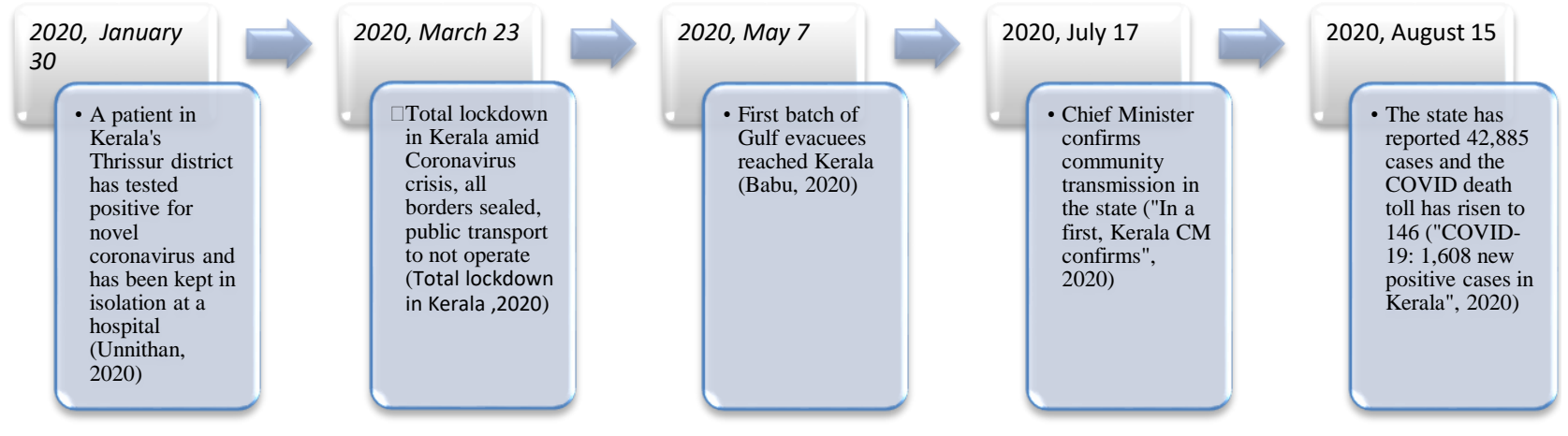

Figure 1. Glimpses of Covid-19 in Kerala Source: Authors

Kerala is acclaimed for high human development index (0.790), and remains in the centre of debates with regards to its model of development. The immediate operational response to control the spread of the virus was a complete nationwide lockdown. It caused a lot of stress and disturbances among diverse segments of the population of Kerala, apart from the spread of fear of disease and loss of further livelihood options (Science the Wire, 2020). Amidst this chaos, an efficient public health delivery system and with people working in government programs as volunteers helped the State to address the crisis to a very great extent (Krishna, 2020). Initially, the State Government brought in mechanisms to support interstate migrants through community kitchen, ration supplies, and the State's Public Distribution System (PDS), and was efficiently catering to the needs of people. India takes pride in its (PDS) as a food security system responsible for providing essential food and non-food commodities to the economically vulnerable sections of the society through government-sponsored shops (Fair Price Shops) at low prices. PDS is established under the Ministry of Consumer Affairs, Food, and Public Distribution and managed jointly with state governments (Ghabru, Devi \& Rathod, 2016). However, the interstate migrants were desperate to return to their home states. The state of Kerala stood on slippery grounds when there was migrant protest upon their need for repatriation (Guest workers take out March, 2020). What the government failed to understand was the interstate migrants' psychological and emotional needs to reach out to their dear ones - their families, neighbourhood and their communities - the immediate support system one relies on at the time of any crisis.

\section{Unpacking the Complex Impacts}

Covid-19 and its ramifications impacted the economy of individual households drastically, and it had repercussions on the psychological well-being of individuals and families. The Kerala expats, who lost their livelihood and returned due to the global crisis were doubly impacted. Social isolation for them added fuel to the fire as they were already undergoing distress and anxiety with regards to their bleak future. The lack of industry and void in the service sector 
added 3.8 million people into the unemployed lot in the State, twice that of the national average (An estimated 12.2 crore Indians, 2020).

As a consequence of social distancing and lockdown, Kerala had the lowest labour participation rate in April 2020 (An estimated 12.2 crore Indians, 2020). 'Unemployment' and the reduced income are not just pushing families to restrict their satisfaction of basic needs, but also lead to physical and psychological distress as well. Even, the employed experience fear of losing their job, leaving themselves and their families in anxiety and stress. The changes in the labour market and the economy of the State has direct and indirect manifestations in the mental health of the population; especially when it is the case of Kerala, whose economy largely depended on NRI remittance and service sector contributions - the major backlash of Covid-19 pandemic (Nair, 2020). Thus, the economic pressure has had a devastating impact on families, primarily resulted in reducing people's capacity to meet basic needs and hurt their psychological and social well-being.

\section{Spike in Domestic Violence}

While lockdown promoted private spaces fostering family cohesion and communication in its initial phase, issues such as domestic violence, parent-youth apathy, disruption of family relations, and human rights violations began to surface (Kumar et al., 2020). Failing to meet the expected role of the sole breadwinner develops anger and anxiety among men resulting in violence against women and children. For years, Kerala has reported a high number of domestic violence cases, and the present pandemic crisis have increased the episodes owing to social distancing, a decline in household income and lockdown restrictions. The District Mental Health Programme recorded up to 700 cases per day during March who sought help for counselling for various familial issues (Kerala: Counsellors witness spike in domestic violence cases, 2020). In the National scenario, according to the reports of National Commission for Women, in 18 days, from 23 March- 10 April 2020, a total of 370 cases related to women were reported out of which 123 were exclusively domestic violence cases (Amid lockdown, NCW receives 123 domestic violence complaints in 18 days, 2020).

\section{Impact on Front Line Health Workers}

Although chronic causalities did not overshadow the scene, people with existing morbidities suffered due to limited access to health care. However, due to an increased number of affected persons, the State suffered a depletion of resources in the health sector, including human resources. The front-line workers including doctors, nurses, ambulance drivers, ASHA (Accredited Social Health Activist) workers, hospital workers, and paramedical staff in the State have been working since January 2020 with the mission of combating Covid-19 cases. The front-line staff risk their lives and are in constant exposure to the virus. Though they were publicly praised for their service, their presence and care in the hospital premises, they felt a level of exclusion back in their neighbourhoods. The discomfort and suffocation experienced by them wearing the Personal Protection Equipment (PPE) in a tropical country climate gear have often resulted in exhaustion. The duty restrictions and fear of contracting the infection deprived most of them of meeting their families (Nair, 2020).

Although there was fewer number of Covid-19 cases among the health workers, there were incidents of undesirable violence and abuse in their practice settings. Episodes of threatening and physical attacks were reported across the State, but the larger goal of reducing the infection left these human rights violations unattended (Sudhish, 2020). Amidst this stigma and violence that decimates their positive spirits, these frontline health workers' mental health needs must also to be factored in. They deserve psychological support; probably a catharsis for some which during the pandemic was completely unattended.

\section{Covid-19 hits the Resource-dependent Communities}

Lockdown not only affected the salaried employees but also the fishermen, farmers and workers from the tourism industry who are 
described as resource-dependent communities (Matarrita-Cascante \& Trejos, 2013). These communities' lives and income are marketdriven on almost a daily basis. As retail stores were shut down, farmers who harvested vegetables and fruits could not sell their produce during March-June 2020 (Ani, 2020). Coastal and fishing communities were pushed to poverty. The Kerala Government's financial assistance of INR 2000 (\$27) for small fishers was also too meagre to make both ends meet. The coastal community of Poonthura-identified and declared as 'super spread area' of Covid-19 protested against police and health workers on complete lockdown measures (Praveen, 2020). This 'Poonthura Protest' gained the attention of social activists and media, projected government's biased measures and insensitiveness showed by labelling Poonthura community as 'uneducated and unmanageable mass' (Essentials not available, 2020).

Though the tribal communities constituted only 1 per cent of the State's population, Covid-19 has not spared them too. The geographical and spatial distribution of these communities secluded them from the general population; many of the tribal families residing along the forest fringes were unaware that the pandemic had engulfed the world (Kuttoor, 2020). Nevertheless, the ignorance about the preventive measures placed them at high risk. The majority working in plantation estates of neighbouring states of Tamil Nadu and Karnataka were carriers of the virus to these hamlets (Thirunelly records its first tribal COVID positive case, official declaration soon, 2020).

\section{The Social Distancing effect in Kerala}

Empirical evidence suggests that pro-social behaviour contributes to positive mental health and social isolation is one of the determinants of mental health conditions (Nazeer, 2020). However, a significant control measure to contain the virus as advocated by WHO (2020) in its operational guidelines to all nations was to maintain social distancing. Social distancing reduces face-to-face contact and social interaction. Covid-19 experience of social distancing in Kerala has manifested differently in different segments of society. For some people, it is a feeling of loss, emptiness, and vacuum. For women, social distancing was the loss of structure and routine in the household chores; its gravity is more when it is the case of working women, struggling to find a balance in 'work from home' milieu (Shashikant, 2020). In addition, because of Covid-19 lockdowns, many people were left unsupported. For example, neighbourhood hostility during the lockdowns left individuals and families with a limited support system, as reaching out to extended family members for support was halted by the lockdown restrictions on commuting.

The aged and elderly, who were termed to be on a high-risk plain, also faced vulnerability and distress. Social distancing brought to the aged fear of morbidity and mortality along with isolation and the fear of being distanced from their children. For some aged and elderly people, the loss of physical touch and presence impacted on their psychological well-being, with many experiencing loss of self-worth, loss of motivation, and loss of meaning to life and living (Addleman, 2020). Ruminating on one's mortality amplifies the worst in people isolation, boredom, anxiety, and despair (Solomon and Greenberg, 2020). Furthermore, the pandemic related instability generated within the households has paved the way to exploitative relationships and disruptive communication patterns that threaten family cohesion and flexibility (Kumar et al., 2020).

The closure of liquor shops in Kerala as part of lockdown measures has increased withdrawal symptoms for alcoholics. Seven died of alcoholism, and several suicide attempts were reported (Sebastian, 2020). The government has opened de-addiction centres and public health care facilities to treat persons with withdrawal symptoms (Sebastian, 2020). Women and children in the family are the first victims of the men's alcoholism and during Covid-19 times; families suffered not knowing how to address the withdrawal symptoms of their male members.

\section{The Burden of Home Learning}


The low-income families had difficulties in meeting the educational needs of their children due to lack of technology and laptops, and internet speeds. Student support mechanisms have entirely left the stage to traditional syllabus-oriented classes to run virtually. Families having more than two children suffer the availability of electronic gadgets at their disposal in order to avail the new system of teaching-learning. Instances, when classes went online while the tribal hamlets in the State remained with no access to electronic devices or the internet, came to the forefront. The Kerala State Education Department launched virtual classes named 'First Bell' for school children so that no student will miss out as schools were closed, however, access to digital literacy was far from reality for children of the marginal communities. The government began talking about e-learning, laptops, and online classes to these geographically vulnerable communities who do not even know about electricity (Kuttoor, 2020).

\section{The Magnitude of Mental Health Needs}

The State of Kerala witnessed a massive rise in mental health needs which found evidence in the reports of Districts' Mental Health Programme (DMHP). As per the data, as many as 30,844 persons were given counselling during March-April 2020 (Stress, stigma and sleep loss: Covid-19 takes a heavy toll on mental health, 2020). Out of 8,659 persons reported of having contacted counsellors seeking help to overcome stress, anxiety, depression, sleep impairment, stigma issues (fear of contracting Covid-19) and other psychiatric issues, 2,436 persons were reported of having mental stress, 1,930 of anxiety, 98 of depression, 789 of sleep impairment, 1,149 of stigma issues and 214 for other psychiatric issues. As many as 2,043 contacted counsellors for social needs (Antony, 2020). There has also been an increase in the cases reported on social stigmatisation among gulf returnees and expats from European countries to Kerala. There have been at least 50 such cases reported in the state in the past 105 days. Expats and returnees from neighbouring states had to face the tantrums and harassment of their neighbours and dear ones (Karindalam, 2020).

In the following discussion, the authors attempt to connect their profession to much work that is required to be done in the context of the pandemic in Kerala.

\section{Social Work Reflection on Kerala Pandemic}

Clearly, all consequences and effects of social isolation giving rise to a wide range of social problems such as self-harm, suicide, substance use and abuse, domestic violence, and child abuse; all have been noticed in Kerala during the pandemic. These social problems pose a threat to an individual, family, and societal well-being (Nicola et al., 2020). The primary goal of social work seeks to assist individuals, families, groups, and communities in need. The pandemic across the globe has prompted every profession to brainstorm the impacts on diverse population groups - women, children, adolescents, and youth, elderly, coastal communities, and tribal groups. For Kerala as a vast coastal state, the post-pandemic rebuilding does require critical and quite crucial interventions from social workers. Initially, the Professional Association of Social Workers in Kerala offered assistance to the government, and where possible, to sit with the state governments and district committees to assist in the social dissemination of the preventive measures and also in public distribution systems. The Kerala social workers were useful in the task of system linkage and system maintenance. However, upon reflection, we believe that beyond such immediate crisis interventions steps, social workers can enhance the personal and social functioning of individuals, families, groups, and communities through psychosocial counselling and this seems to be emerging as a major unchartered task in the current times. Professional social workers have a pivotal role to play in this venture as mental health professionals, educators, researchers, coordinators of action projects, policymakers, and consultants. Thorpe (2014) provides timely encouragement for Social Work practitioners, explaining that

It is empowering for ourselves and for our service users to recognise that, 
nonetheless, much can be accomplished through practice which endorses and enacts a commitment to both respecting humanity, dignity and worth of all persons, and to advancing the cause of achieving greater social justice. What we need are vision and passion. Our service users hope that you will embrace this challenge. (Thorpe, 2014, p.7).

The approach to human well-being could be emancipatory when it addresses social and structural inequalities; it is empowerment when it raises critical consciousness and facilitates action, and it is strengths-based when it is focused on building inner strengths and capacities and mobilises external resources to combat future challenges. Covid-19 crisis calls for the adoption of this strength-based approach to well-being (Pulla, 2017). The strength-based approach is a manner of working with individuals, families, organisations grounded in the principle that those individuals have existing competencies; have resources; are capable of learning new skills and problem-solving; can use existing competencies to identify and address their concerns, and can be involved in the process of healing and self-health.

\section{Conclusion}

Covid-19, the pandemic has vehemently hit human life across the world, but in the case study area, Kerala State it has caused havoc and further bleeding for the state coffers. The state is still reeling from the economic recovery measures from its previous epidemic - the Nipah virus and the consecutive floods in 2018 and 2019. People are experiencing mixed emotions, rather a numbness to everything around them. The unique range of human problems, structural inequalities, and unprecedented disasters make the social work profession so demanding; calling for remedial, restorative, preventive, and strength-based approaches to meet human needs, address human problems and enhance human capacities for overall well-being. In the post-Covid-19 period, a State like Kerala requires large economic and social rebuilding actions and social work.

\section{References}

Addleman, M. (2020, April 20). COVID-19 social distancing having significant impacts on mental health, study shows. Medical Xpress, https://medicalxpress.com/news/2020-04covid-social-distancing-significant-impacts.html

Amid lockdown, NCW receives 123 domestic violence complaints in 18 days. (2020, April 10). The Week.

https://www.theweek.in/news/india/2020/04/ 10/amid-lockdown-ncw-receives-123-domesticviolence-complaints-in-18-days.html

An estimated 12.2 crore Indian lost their jobs during corona virus lockdown in April: CMIE. (2020, May 7). The Hindu.

https://www.thehindu.com/data/data-over-12crore-indians-lost-their-jobs-during-thecoronavirus-lockdown-inapril/article31520715.ece

Ani. (2020, April 11). Kerala farmers face issues in selling vishu produce 'cucumbers, watermelons' amid COVID-19 lockdown. The New Indian Express.

https://www.newindianexpress.com/states/ker ala/2020/apr/11/kerala-farmers-face-issues-inselling-vishu-produce-cucumbers-watermelonsamid-covid-19-lockdown-2128815.html

Antony, T. (2020, May 12). Stress, stigma and sleep loss: COVID-19 takes a heavy toll on mental health. The New Indian Express. https://www.newindianexpress.com/cities/koc $\mathrm{hi} / 2020 / \mathrm{may} / 12 /$ stress-stigma-and-sleep-losscovid-19-takes-a-heavy-toll-on-mental-health2142190.html

Australian Association of Social Workers. (2010). Code of Ethics.

https://www.aasw.asn.au/document/item/120 1

Babu, A., \& Jose, S. (2019). Perspectives on Social Work Education and Professional Practice: The Kerala Scenario. International Journal of Management and Social Sciences, 9(2),151-156.

Babu, R.(2020, May 7).First batch of Gulf evacuees will reach Kerala today. Hindustan Times. https://www.hindustantimes.com/india- 
news/first-batch-of-gulf-evacuees-will-reachkerala-today/story-

wZkLO7OaUJeehjwdHmrxwl.html

Balakrishnan,P. (2019, August 22). The 'Kerala Model' is unsuitable. The Hindu.

https://www.thehindu.com/opinion/op-ed/thekerala-model-is-

unsustainable/article29213883.ece

CM focuses on economic growth. (2020, May 05). The Hindu.

https://www.thehindu.com/news/national/ker ala/cm-focusses-on-economicgrowth/article31505458.ece

COVID-19: 1,608 new positive cases in Kerala, on Saturday, 803 recover. (2020, August,15).Onmanorama.https://www.onmano rama.com/news/kerala/2020/08/15/covid-19cases-kerala-pinarayi-vijayan-health-shailajacoronavirus.html

C S, Shaijumon. (2020). COVID-19 and its Economic Impacts in Kerala. Kerala Calling, 40(6), 19-20

Dave, S. (2020, March, 26). Covid-19: Companies rope in psychiatrists, experts for emotional counselling of work from home employee. The Economic Times.

https://economictimes.indiatimes.com/news/c ompany/corporate-trends/covid-19-companiesrope-in-psychiatrists-experts-for-emotionalcounselling-of-work-from-homeemployees/articleshow/74819122.cms?from $=m$ $\mathrm{dr}$

Dominelli, L. (2004). Social work: Theory and practice for a changing profession. Cambridge, ENG: Polity Press.

Essentials not available Poonthura residents protest amid triple lockdown due to 'local transmission (2020, July 10). New Indian Express.

https://www.newindianexpress.com/states/ker ala/2020/jul/10/essentials-not-availablepoonthura-residents-protest-amid-triplelockdown-due-to-local-transmissio2167921.html

Freire, P. (1970). Pedagogy of the oppressed. New York, NY: Herder \& Herder.
Ghabru, M. Devi, G. Rathod, N. (2016). Public distribution system in India: Key issues and challenges, Indian Journal of Economics and Development, 13 (4):747-754 https://www.researchgate.net/publication/321 771115_Public_Distribution_System_in_India_K ey_Issues_and_Challenges

Guest workers take out march in Kerala seeking arrangements to go home. (2020, April 30). The Federal.

https://thefederal.com/states/south/kerala/gu est-workers-take-out-march-in-kerala-seekingarrangements-to-go-home/

Herz, M., \& Johansson, T. (2011). Critical social work - Considerations and suggestions. Critical Social Work, 12(1), 28-45.

In a first, Kerala CM confirms community transmission of Covid-19. (2020, July 17). Hindustan Times.

https://www.hindustantimes.com/indianews/in-a-first-kerala-cm-confirms-communitytransmission-of-covid-19/story

Karindalam,V. (2020, July 3). 'COVID-19 stigma'$A$ crisis that requires urgent cure, Times now.https://www.timesnownews.com/mirrornow/in-focus/article/covid-19-stigma-a-mentalhealth-crisis-that-requires-urgent-cure/615640

Kerala: Counsellors witness spike in domestic violence cases. (2020, April 5). The Times of India.

https://timesofindia.indiatimes.com/city/kochi/ kerala-counsellors-witness-spike-in-domesticviolence-cases/articleshow/74992425.cms

Krishna, Y. (2020, May 23). India's Kerala Is Combating COVID-19 Through Participatory Governance. IDN-Indepth

News.https://www.indepthnews.net/index.php /sustainability/health-well-being/3563-india-skerala-is-combating-covid-19-throughparticipatory-governance

Kumar, A. Mehta, B. Singh., Mehta, S., (2020, April 17). The link between lockdown, COVID19 , and domestic violence. India Development Review. https://idronline.org/the-link-betweenlockdown-covid-19-and-domestic-violence/ 
Kuttoor, R. (2020, March 28). Tribes, ignorant of COVID 19, briefed on perils. The Hindu.

https://www.thehindu.com/news/national/ker ala/tribes-ignorant-of-covid-19-briefed-onperils/article31194917.ece

Kuttoor, R.(2020, June 3) e-learning lost on tribes in Pathanamthitta forests, The Hindu. https://www.thehindu.com/news/national/ker ala/e-learning-lost-on-tribes-in-pathanamthittaforests/article31742906.ece

Marques, Emanuele Souza, Moraes, Claudia Leite de, Hasselmann, Maria Helena, Deslandes, Suely Ferreira, \& Reichenheim, Michael Eduardo. (2020, April 30). Violence against women, children, and adolescents during the COVID-19 pandemic: overview, contributing factors, and mitigating measures. Cadernos de Saúde Pública, 36(4), e00074420. https://dx.doi.org/10.1590/0102$311 \times 00074420$

Matarrita-Cascante, D., \& Trejos, B. (2013). Community resilience in Resource dependent communities: A comparative case study. Environment and Planning, A 45(6):1387-1402 https://www.researchgate.net/publication/271 531451_Community_resilience_in_resourcedependent_communities_A_comparative_case _study\#: :text=2005) \%20among \% 20others.,Resource\%20dependent \%20communities\% 20have\%20been \%20 observed\%20as\%20communities\%20whose\%20 primary, Cascante $\% 20$ and $\% 20$

Trejos\%2C\%202013)\%20.

Morley, C. (2003). Towards Critical Social Work Practice in Mental Health. Journal of

Progressive Human Services, 14(1), 61-84, https://ezproxy.tiss.edu:2102/doi/abs/10.1300/ J059v14n01_05?src=recsys

Nair, P. (2020, May 15). Putting Plans In Place To Rehabilitate Expats: Kerala Finance Minister Thomas Isaac. Outlook.

https://www.outlookindia.com/website/story/i ndia-news-putting-plans-in-place-torehabilitate-expats-kerala-finance-ministerthomas-isaac/352827

Nair, S. (2020, May 04). Tackling COVID-19 in Kerala: Hailed by patients and shunned by society, hospital staff recounts working on front-line. Firstpost.

https://www.firstpost.com/health/tacklingcovid-19-in-kerala-hailed-by-patients-andshunned-by-society-hospital-staff-recountsworking-on-front-line-8285431.html

Nazeer, S. (2020). Lockdown- A blessing in disguise. Kerala Calling, 40(6), 45-46

NCBI Resources. (2013, December 18). Subjective Well-Being: Measuring Happiness, Suffering, and Other Dimensions of Experience. https://www.ncbi.nlm.nih.gov/books/NBK1744 73/

New Economics Foundation (2012). Measuring Well-being: A guide for practitioners, London: New Economics Foundation.

Nicola, M., Alsafi, Z., Sohrabi, C., Kerwan, A., AlJabir, A., Losifidis, C., Agha, M., Agha, R., (2020, April 17). The socio-economic implications of the coronavirus pandemic (COVID-19): A review. Elsevier Public Health Emergency Collection. 78: 185-193.

doi: 10.1016/j.ijsu.2020.04.018

Praveen, S. (2020, July 10). Corona virus rumours fuel protest in Poonthura, Health Minister appeals for calm. The Hindu. https://www.thehindu.com/news/cities/Thiruv ananthapuram/rumours-fuel-protests-inpoonthura-heath-minister-appeals-forcalm/article32042675.ece

Pulla, V. (2017). Strengths-based approach in social work: A distinct ethical advantage. International Journal of Innovation, Creativity and Change, 3(2), 97-114.

COVID-19: Taking heed from Kerala's Mental Health Interventions. (2020, March 27). Science the Wire.

https://science.thewire.in/health/covid-19kerala-mental-health/

Sebastian, S. (2020, April 3). COVID-19: Kerala grapples with alcoholism amid lockdown, 'DownToEarth', https://www.downtoearth.org.in/news/health/ covid-19-kerala-grapples-with-alcoholism-amidlockdown-70202 
Shashikant, U. (2020, August 24). How corona virus pandemic changed the lives of working women. Economic Times.

https://economictimes.indiatimes.com/wealth/ plan/how-the-coronavirus-pandemic-haschanged-the-lives-of-workingwomen/articleshow/77688497. $\mathrm{cms}$ ?from $=\mathrm{mdr}$

Sher, L. (2020). The impact of the COVID-19 pandemic on suicide rates, QJM: An International Journal of Medicine, https://academic.oup.com/qjmed/article/doi/1 0.1093/qjmed/hcaa202/5857612

Solomon, S. and Greenberg, J. (2020, May 21). Coronavirus reminds you of death - and amplifies your core values, both bad and good. The Conversation.

https://theconversation.com/coronavirusreminds-you-of-death-and-amplifies-your-corevalues-both-bad-and-good-137588

Stress, stigma and sleep loss: COVID-19 takes a heavy toll on mental health. (2020, May 12). The New Indian Express.

https://www.newindianexpress.com/cities/koc hi/2020/may/12/stress-stigma-and-sleep-losscovid-19-takes-a-heavy-toll-on-mental-health2142190.html

Sudhish,N. (2020, April 3). Health workers battle abuse and threats too. The Hindu. https://www.thehindu.com/news/national/ker ala/health-workers-battle-abuse-and-threatstoo/article31252776.ece

Thirunelly records its first tribal COVID positive case, official declaration soon. (2020, July 1 ) onmanorama.

https://www.onmanorama.com/news/kerala/2 020/07/01/first-tribal-covid-positive-casewayanad-kerala.html

Thorpe, R. (2014). Introduction to areas of Social Work practice in mental health. In A. P. Francis (Ed.), Social Work in mental health: Areas of practice, challenges and way forward (pp. 3-8). Sage publications.

Total lockdown in Kerala amid Coronavirus crisis, all borders sealed, public transport to not operate. (2020, March 23). India TV News Desk. https://www.indiatvnews.com/news/india/coro navirus-kerala-total-lockdown-borders-sealedpublic-transport-600803

Unnithan, G. (2020, January 30). Kerala reports first confirmed coronavirus case in India. India Today.

https://www.indiatoday.in/india/story/keralareports-first-confirmed-novel-coronavirus-casein-india-1641593-2020-01-30

World Health Organization (WHO). (2018). Mental health: strengthening our response. https://www.who.int/en/news-room/factsheets/detail/mental-health-strengthening-ourresponse

World Health Organization. (2020 May 22). COVID-19 strategic preparedness and response plan operational planning guidelines to support country preparedness and reponse.

file:///Users/Arya/Downloads/covid-19-sprpoperational-planning-guidelines-to-supportcountry-preparedness-and-response-

(22may20)\%20(1).pdf

\section{Conflict of Interest}

The authors have not received any funding for the article and they have no affiliation with or involvement in any organisation or entity with any financial interest. The authors declare that there is no conflict of interest.

\section{Acknowledgments}

The authors are very grateful to Dr Venkat Pulla, for his assistance with all suggestions for this article from the time we wrote the first abstract at his behest. We are also grateful to the referees for several suggestions and for seeing earlier drafts of this article. We place an account of gratitude to all the reviewers for their thoughtful comments and efforts towards improving our article.

\section{About the Authors}

Dr Elsa Mary Jacob is an academic in Social Work at Bharata Mata College, Kerala, India, with extensive experience of practice, teaching, research and training. Her experience in social work research is focused on intervention studies with adolescents and youth, and evaluation studies of programmes. Her practice experience in Child Welfare, Community 
Development, Women Empowerment, Community Based Rehabilitation (CBR) and Corporate Social Responsibility (CSR) alliance with white Ribbon Alliance India (WRAI) programme have contributed remarkably to the Social Work teaching. As a researcher Dr Jacob was one of the pioneers who initiated Bal Panchayat, and developed a model for working with disadvantaged youth in Kerala.

Ms Arya Chandran L is Assistant Professor of Social Work at Bharata Mata College, India. She is young academician with extensive research experience in gender, inequality, marginal communities and public health. Her publications are mostly on health and education of tribal community in India. Her academic career envisions contributing to update the indigenous knowledge base of social work curriculum. She is currently working on her doctoral thesis on the gender aspects of fisherwomen's health in the state of Kerala.

Abraham P. Francis is an Associate Professor, and currently the Head of Academic Group in Social Work and Human Services at James Cook
University, Australia. Dr Francis is a research fellow at the department of social work, Stellenbosch University, South Africa and an Adjunct Faculty with Prasanna School of Public Health, MAHE, Manipal, India. In 2018, Dr Francis received the NAPASWI lifetime achievement for his outstanding contribution to Social Work Education.

\section{Author Contribution Statement}

Following is the contribution made by all authors in completing the article titled 'Human Wellbeing and Pandemic crisis: Implications for Social Work Practice from Kerala Experience'.

Elsa Mary Jacob: conceptualisation, methodology, critical analysis, writing original draft

Arya Chandran L: conceptualisation, methodology, critical analysis, writing original draft

Abraham Francis: conceptualisation methodology, critical analysis, writing original draft reviewing and preparing the final draft 